\title{
United States and France: Imprisonment and Torture From the End of WWII to the Algerian War
}

\author{
Francesca Somenzari \\ University of Turin, Turin, Italy
}

\begin{abstract}
Mistreatment and violation of international laws are recurrent events during Second World War (WWII) and torture is a frequent method used in the Algerian War. This paper investigates the escalation of violence which, in some cases, degenerates into torture and offers a comparison between the situation of Axis Prisoners of War (1943-1946) and the imprisonment's conditions in Algeria (1954-1962). In spite of the temporal interval and different political contexts, in some cases there's a strange "continuity”.

Keywords: prisoners of war, WWII, torture, mistreatment, Geneva Convention
\end{abstract}

\section{Introduction}

Imprisonment and torture have always accompanied the history of humanity. Torture, however, even more than imprisonment, has devised new coercive solutions, new tools, and new ways depending on the goals it set itself. In pre-classic criminal law, torture was considered a mean of obtaining evidence rather than a corporal punishment. In a time span that stretches from ancient times to the present day, torture has become sophisticated and pondered. Even in this field, modernity has expressed its full potential and 20th-century technological paraphernalia played its part.

As the author said, torture crosses centuries of history and very different experiences. In Greek-Roman times, it was used against slaves in particular, but also against free (but foreign) citizens and it consisted in four basic forms:

1. The nailing to a stake (like the crucifixion), as reported against a war enemy by Herodotus in his Histories;

2. Impalement (that is, running a pole through the trunk of the body from the anus to the throat), attested by historian Duris of Samos with reference to the war between Athens and Samos in 439 B.C.;

3. The stocks, a tool consisting in an iron collar chained to a column, which dates back to 820 A.D.;

4. Branding by means of a red-hot iron, considered to be the lightest type of torture of ancient times and used to humiliate the defeated enemy ${ }^{1}$.

During the first three torments, the victim could have to endure hours of agony before the executioner decided to put an end to their suffering.

If we move slightly away from warfare, the range of tortures was even wider with the wheel, the stake, the stretching, mutilation, the pincers and the tongs, the rack, the suspension, the drowning, the quartering, the

\footnotetext{
Francesca Somenzari, Ph.D., Research Fellow, Cultures, Politics and Society Department, University of Turin.

${ }^{1}$ In relation to it, Plutarch is a good source of information.
} 
boiling, the ripping, the Brazen Bull, and the Iron Maiden.

Some of these methods have also been employed in modern wars: think for instance about waterboarding (drowning), frequently used by the United States of America (USA) against Islamic prisoners in Abu Graib in Iraq and in Guantanamo in 2003 (Bonini, 2004).

In the 20th century, war torture developed new techniques and this century was able to combine subtle tortures with explicit, really tough ones.

However, before getting into details as far as my three cases are concerned, that is:

1. The mistreatment of Italian and German prisoners in American hands at the end of Second World War (WWII);

2. The tortures against the Germans by the French between 1944 and 1948;

3. The tortures against the Algerians by the French during the Algerian War.

It is fundamental to recall and be clear about Raphaëlle Branche's lucid definition of torture:

Torture is an absolute act of war. It immediately creates a radical inequality between the one who enjoys all the rights and the one who has none, since the latter is not recognized as equal, neither in the war context, nor on a human level. Torture amounts to the realization of a victory over the individual. (Branche, 2001, p. 325)

\section{Italians and Germans in American Hand at the End of WWII}

The situation Germans and Italians face between the end of the WWII and the early post-war era represents the first step in an escalation of mistreatment and violence which, in some cases, degenerates into torture. The author would like, however, to stress the fact that, differently from the second and the third, this first case is not totally torture yet, although it is very close to it. We are faced with an intermediate situation, which is more than maltreatment and less than real torture.

The Italian prisoners in American hands, after September 8, 1943, find themselves in a different situation compared to the war, as the armistice has given the Italian government the illusion of co-belligerency, which at first prompts Badoglio and the High Commissioner for war prisoners, Pietro Gazzera, to make concessions and negotiations which, however, do not end in the way and upon the conditions hoped for by them (Conti, 2012). Suddenly, within USA prison camps, the Italians are faced with the choice to voluntarily join (therefore without the mediation and the full consent of the Italian government) the co-operation with the allied forces or to refuse it. Those who refuse to sign the I promise, that is, the collaboration agreement (and decide to wait for further instructions from the Italian government), are immediately discriminated against and treated in open violation of the 1929 Geneva's Convention. How are they discriminated against? These Italians, labeled as "fascist prisoners," are transferred to special camps (therefore far from the other prisoners who have decided to cooperate), particularly to the Hereford (Texas) camp, where they are subjected to a harsh system of deprivation and violence. The USA military substantially decreases the food rations to which these prisoners are entitled, thus starting a regime called, not without reason, of starvation and tough violence, consisting in night round-ups during which the Italian prisoners are beaten up and often massacred in their sleep (Tumiati 1985, pp. 85-86). All of this aims at forcibly inducing these Italians to accept the cooperation with the Allies. For the latter, their acceptance does not bring about any particular material or economic advantage, but it has a precious political value in terms of consensus, mainly.

This type of violence (which coincides with the so-called coup, punch, or beating), which may at first seem bland, is in fact defined by Raphaëlle Branche as the first step within torture methods. 
Let us read some testimony given by non-cooperating Italian prisoners in their memoirs:

We are subjected to sudden irruptions. Suddenly, in the silence of the night, a roar of vans, the sound of troops' running steps, screams, shouting, while the lights in the turrets are rotating faster than usual.

We hear a group breaking into the barrack next to ours: cudgel strokes, laments. Now, it is our turn. The door bangs open and on the threshold the gigantic silhouette of a soldier in battle gear appears, all the more black because the headlights of a jeep are projected on his back, creating scary light effects. They are rotating the cudgels when they are gone we rush to the wounded ones. Bruises, blood, numbness. (Tumiati, 1985, pp. 85-86)

This climate of intimidation, as well as the diet, consisting in one slice of bread and one eight of salted fish per day, begins in May 1944 and lasts until early 1946, the year of the repatriation. Despite the protests for the abuse in breach of the 1929 Convention, the commander at Hereford camp, colonel Carlworth, usually replies: War is war. The Geneva Conventions are the Geneva Conventions, but we are in the USA here. The author thinks you would better tell your officials to collaborate. It is better for them (Mieville, 1948, p. 67).

Beside forms of physical violence, there exist methods of psychological torture, like feigning the shooting of some prisoners, so as to induce the prisoners to desist from their resistance. The violence exerted on the prisoners, both as starvation and physical mistreatment, serves a precise purpose. It is violence with a political objective.

The case of the German prisoners in American hand in the context of the end of the WWII in Europe has got slightly different characteristics, which have the taste of genuine war revenge, like we will see in the second case (the one of the Germans in French hands). We are at the beginning of 1944, when the USA army starts penetrating the German territory and, as it gradually takes prisoners, it rounds them up in provisional camps, Rheinwiesenlager, on the left-hand side of the river Rhine. We are looking at a case which stands between the inability, on the one hand, to actually assist these prisoners and the unwillingness, on the other hand, to look after them. It is a type of neglectful and inhuman treatment which has got the intuitive and logical connotations of war revenge. The Germans are kept outdoors behind barbed-wire fences, without shelter, and unfed.

Let us read the worried testimony given by a local bishop to the Red Cross International Committee:

Act urgently, every day notes are thrown from the fences, saying "Help us, we are starving to death” (August 23, 1945, in G 3/26h, France-Allemagne)

Another testimony, gathered by the Deutsches Büro für Friedensfragen, reveals the clear intent of this maltreatment:

In the spring of 1945, in Rheingönnheim, near Ludwigshafen, there was a large USA concentration camp. The prisoners had to camp outdoors without tents, so they were forced to dig up holes in the ground and use them as shelters. The tents the prisoners still possessed were taken away from them. Their diet was bad (May 1945, in Z 35-327, Deutsches Büro für Friedensfragen, Bundesarchiv Koblenz)

And then:

Inside the camp shots were fired by the guards, and not by accident, but on purpose (May 1945, in Z 35-327, Deutsches Büro für Friedensfragen, Bundesarchiv Koblenz)

It is quite clear that if malnutrition can be attributed the lack of alimentary resources on the part of the USA army in the context of 1945 Germany, taking forcibly the tents away from the prisoners and shooting them from the camp's control turrets is not to do with impossibility or neglect, but with sheer war revenge. The 
creation of such enclosures comes shortly after the Anglo-American discovery of Nazi concentration camps, so we must validate, rightfully, and based on the available sources, the hypothesis of sometimes subtle, other times explicit tortures against the German prisoners of the first phase, that is, those captured between the winter and the spring of 1945.

If the violence inflicted on the Italian prisoners has a political objective, that is, harvesting as much consent as possible to the collaboration project, this is where the war retaliation phase begins.

The aspect which must be pointed out in this case and in the next ones is that it is the subaltern, low ranks, the wardens, in this case of Polish nationality, who play the part of the torturers, under the complicit, and absolving gaze of the high commands.

\section{Germans in French Hand}

The case of the German prisoners in French hand at the end of and after the WWII is a clear example of explicit torture.

Before analyzing the nature of such practices, it is fundamental to start by saying that, not by chance, the German soldiers preferred to be captured by the Anglo-Americans than by the French or the Russians, who were considered, for reasons that we're not going to deal with here, inexorable jailers.

Besides further reducing the food rations in the camps on the left-hand side of the Rhine, where the French army replaced the American one between the spring and the summer of 1945. A fact that, because of the harshness of the conditions, attracted the attention of the press, particularly of "Le Figaro", which, referring to the prisoners, talks about "skeletons" wandering around the fenced areas, and of "Le Monde", that titles an article like this: Un prisonnier, même allemand, est un être humain and adds:

Just like today we are talking about Dachau, in 10 years' time, we will be talking about camps like... (Somenzari, 2011, p. 95)

The French adopted real torture methods, like electrocution and branding. Dossier G 25/5, found in the archive of the International Committee of the Red Cross in Geneva, reports some of these cases that were quite common in the military prisons in Toulouse and Bordeaux in particular. Let us read a report of the Red Cross:

During the visits to the military prisons in Toulouse and Bordeaux, Mr. Boissier was able to spend some time with many prisoners detained there, who made some complaints about the methods employed with them during the questioning. These prisoners claimed to have suffered very cruel corporal punishments: branding with fire-heated irons, electrocution of the gentitals, punches. (September 12, 1946, in G25/5, France 1946, Comité International de la Croix-Rouge)

We stand before, in part, those torture methods that the French will employ, without limits and hesitation, against the Algerian prisoners between 1954 and 1962, and that essentially amount to five: punching, hanging, drowning, waterboarding (also known as water torment), or electrocution and rape (Branche, 2001, p. 236). Of these five methods, used systematically during the Algerian war, three are applied against the Germans between the end of the WWII and the early post-war period. A sense of impunity probably accompanies the spread of these forms of torture against the Germans. This is due to the fact that the condition of reciprocity has died out and to the breach of the Geneva Convention, a fact made possible by the signing of the unconditional surrender on the part of the German High Command. 


\section{The Case of the Algerian War}

In the 1900s, the Algerian War is the case in point for illustrating the use and the spread of torture methods. As Vidal-Naquet reports:

Arrested by the police, often tortured, judged by biased tribunals drenched in a racist spirit, after being sentenced they were put back in the hands of an administration which depended on the police itself. Everything happened within a closed circuit, of which torture was an integral part (Vidal-Naquet, 1963, p. 28).

In this war, torture becomes a system, involving several levels of the state: the army, the police, the administration (Thénault, 1998). As Vidal-Naquet (1963, pp. 31-32) pointed out, the judiciary is often an accomplice, too, as it does not have the prisoners who show very evident injuries undergo medical scrutiny.

But the element that places the Algerian war on a totally different level from previous conflicts is the public admission and tolerance of torture, represented by the Wuillaume ${ }^{2}$ report: it is the political seal of this state of affairs. In this report, not only are the tortures practiced in Algeria on those who are suspected listed, tortures that are the prerogative of "every police", from the gendarmerie to the judicial police, through the information service, but these methods of torture are also authorized. How? Wuillaume puts it on paper that "Such procedures as the use of the water tube and electricity, if used with caution, would produce a shock more psychological than physical, and therefore would be free from excessive cruelty” (Vidal-Naquet, 1963, p. 32 ). Therefore, for the first time, a senior official, not belonging to the army or the police, proposes to legalize torture and to restore. As Vidal-Naquet writes what in the Middle Ages was called "the water torture", adding "the more modern use of electricity to it" (Vidal-Naquet, 1963, p. 33). It is a report that, due to its shocking conclusions, could not be accepted even by Jacques Soustelle, then General Governor of Algeria, and a longstanding supporter of French colonialism. If at the state level, torture still remained theoretically forbidden, it was accepted that the torturers would be covered by the superior authority.

In the context of the end of the WWII, and soon thereafter, it is that of the racial nature that totally distinguishes the Algerian case from the previous ones. Vidal-Naquet, referring to the various power organs of the state and in particular to the police, the prefects, the sub-prefects, the head of the administration, writes:

Even though these gangs tore each other to pieces, they were then firmly united in imposing the racial supremacy of the European on the Muslim. (Vidal Naquet, 1963, p. 33)

Here is the element that distinguishes this type of conflict from those previously illustrated and which forms the basis of this system of torture. This war could, in actual fact, be equated with a colonial war (Labanca, 2007), not of conquest but of maintenance, and in this dimension the fundamental element of nationality comes into play for the French. Algerians are not considered citizens of a state on a par with France, even if they themselves continue to repeat: l'Algérie est la France. There is an idea of possession above all, certainly not of citizenship.

\section{Conclusion}

Even if Geneva Conventions and other agreements have tried to protect prisoners of war over the 20th-century, mistreatments and tortures found their "spaces", mainly at the end of WWII and during the Algerian War. Rare cases of bad treatment towards German prisoners in American hand became habits in

\footnotetext{
${ }^{2}$ In 1954, Roger Wuillaume, a government inspector, was sent to Algeria to investigate numerous reports of torture.
} 
French hand; sporadic examples of explicit torture during WWII were regular systems in the Algerian War.

\section{References}

Ambrose, S., \& Bishof, G. (1992). Eisenhower and the German POWs: Facts against falsehood. Baton Rouge: Louisiana State University Press.

Beaumont, J. (2007). Prisoners of war in the Second World War. Journal of Contemporary History, 42(3), 535-544.

Böhme, K. (1973). Die deutschen Kriegsgefangenen in amerikanischer hand: Europa (German prisoners of war in American hand: Europe). Bielefeld: Gieseking.

Bonini, C. (2004). Guantanamo: Usa, viaggio nella prigione del terrore (Guantanamo: United States, trip to the terror's prison). Turin: Einaudi.

Branche, R. (2001). La torture et l'Armée pendant la guerre d'Algerie (1954-1962) (Torture and Army during the Algerian War (1954-1962)). Paris: Gallimard.

Cochet, F. (1998). Soldats sans armes, la captivité de guerre: Une approche culturelle (Soldiers without weapons, being held prisoner: A cultural approach). Bruylant, Bruxelles

Conti, F. (2012). I prigionieri italiani negli Stati Uniti (Italian prisoners of war in the United States). Bologna: Il Mulino.

Keefer, L. (1992). Italian prisoners of war in America (1942-1946). New York, NY: Praeger.

Labanca, N. (2007). Guerre coloniali e guerre europee: Il problema del nemico (Colonial and European Wars: The enemy problem). In G. Gribaudi (Ed.), Le guerre del Novecento (Wars of the Twentieth Century) (pp. 49-56). Naples: L'Ancora del Mediterraneo.

Lefeuvre, D. (2005). Chère Algérie: La France et sa colonie (1930-1962) (Dear Algeria: France and her colony (1930-1962)). Paris: Flammarion.

Mieville, R. (1948). Fascists' criminal camp. Rome: Edizioni Corso.

Moore, B. (1996). Prisoners of war and their captors in World War II. Oxford: Berg.

Smith, A. (1984). Die deutschen Kriegsgefangenen in Frankreich (1945-1949) (German prisoners of War in France (1945-1949)). Vierteljahrshefte für Zeitgeschichte (Quarterly Review for Contemporary History), 31(1), 103-121.

Somenzari, F. (2011). I prigionieri tedeschi in mano statunitense in Germania (1945-1947) (German prisoners of war in American Hand in Germany (1945-1947)). Turin: Zamorani.

Somenzari, F. (2013). 8 settembre 1943: Gli Stati Uniti e i prigionieri italiani (September 8, 1943: United States and Italian prisoners of war). Rome: Aracne.

Thénault, S. (1998). Armée et justice en guerre d’Algérie (Army and judicial system during the Algerian War). Vingtième Siècle: Revue D'Histoire (Twentieth Century: History Review), 57, 104-114.

Thénault, S. (2005). Histoire de la guerre d'indépendance algérienne (History of the Algerian Independence War). Paris: Flammarion.

Tumiati, G. (1985). Prigionieri nel Texas (Prisoners in Texas). Milan: Mursia.

Vidal-Naquet, P. (1963). Lo stato di tortura (The state of torture). Bari: Laterza.

Worral, J. (1990). Italian prisoners of war in the United States: 1943-1945. In J. Scelsa (Ed.), Proceedings of The XXI Annual Conference of the American Italian Historical Association (pp. 253-261). The American Italian Historical Association, New York. 